\title{
KAJIAN HUKUM KETENAGAKERJAAN TERHADAP PERATURAN MENTERI TENAGA KERJA DAN TRANSMIGRASI NOMOR 19 TAHUN 2012
}

\author{
Susilo Andi Darma* \\ Bagian Hukum Perdata, Fakultas Hukum Universitas Gadjah Mada, Yogyakarta \\ Jalan Sosio Yustisia Nomor 1, Bulaksumur, Sleman, D.I. Yogyakarta 55281
}

\section{Abstract}

Constitutional Court Decision 27/PUU-XI/2011 followed up by the Minister of Manpower and Transmigration No. 19 of 2012 is still causing problems. Therefore, this article discussed the outsourcing arrangement after the enactment of the Minister of Manpower and Transmigration No. 19 of 2012. The result of this paper was outsourcing arrangement according to the Minister of Manpower and Transmigration No. 19 of 2012 was not yet right.

Keywords: outsourcing, TUPE, constitutional court.

\section{Intisari}

Putusan Mahkamah Konstitusi No. 27/PUU-XI/2011 yang ditindaklanjuti oleh Peraturan Menteri Tenaga Kerja dan Transmigrasi No. 19 Tahun 2012 masih menimbulkan permasalahan. Oleh karena itu, tulisan ini membahas mengenai pengaturan outsourcing setelah ditetapkannya Peraturan Menteri Tenaga Kerja dan Transmigrasi No. 19 Tahun 2012. Hasil dari tulisan ini adalah pengaturan outsourcing menurut peraturan Menteri Ketenagakerjaan dan Transmigrasi No. 19 Tahun 2012 masih belumlah tepat.

Kata Kunci: outsourcing, TUPE, Mahkamah Konstitusi.

\section{Pokok Muatan}

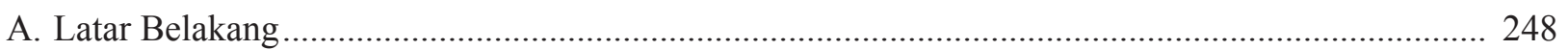

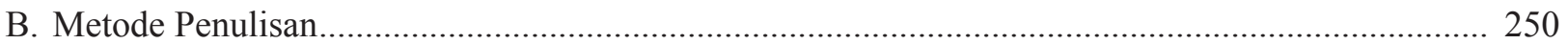

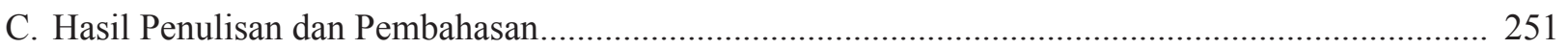

1. Outsourcing di Beberapa Negara di Dunia (India, Cina, dan Jerman) ........................................ 251

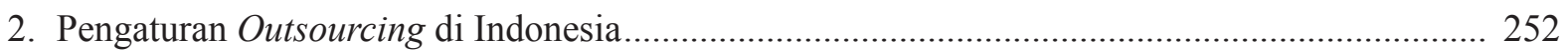

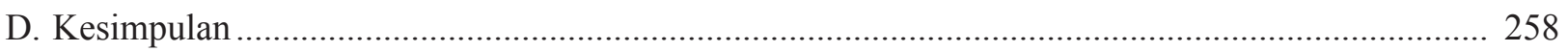

Email korespondensi: anhdie@ugm.ac.id 


\section{A. Latar Belakang}

Hukum Perburuhan lahir terkait erat dengan Revolusi Industri yang terjadi di Inggris pada abad 19. Pada saat itu merubah hubungan antara majikan dan buruh dalam proses produksi. Proses produksi lebih mudah untuk dijalankan karena telah dibantu oleh mesin-mesin uap. Mekanisasi yang terjadi menimbulkan dampak terhadap perusahaan kecil, banyak pabrik-pabrik yang mempekerjakan buruh, kondisi pabrik yang tidak sehat dan berbahaya bagi anak-anak dan perempuan yang dipekerjakan di sana. Hal inilah yang melatarbelakangi adanya hukum perburuhan. ${ }^{1}$

Perkembangan ekonomi global dan kemajuan teknologi yang demikian cepat membawa dampak timbulnya persaingan usaha yang begitu ketat dan terjadi di semua lini dan dengan adanya persaingan yang kompetitif sehingga pengusaha dituntut untuk dapat merespon dengan cepat dan fleksibel dalam meningkatkan pelayanan pelanggan. Hal ini menyebabkan pengusaha harus dapat mengatur strategi dalam menjalankan usahanya agar tetap dapat bersaing dalam mempertahankan roda usahanya. Pengelolaan perusahaan harus dilakukan secara efektif dan efisien dengan tetap mengedepankan tercapainya peningkatan hasil produksi dan pemenuhan kebutuhan masyarakat. Tetapi, hal ini tidaklah mudah untuk dilakukan karena banyak faktor yang harus diperhatikan salah satunya biaya operasional perusahaan.

Salah satu jalan untuk mengurangi biaya operasional perusahaan yaitu dengan cara melakukan outsourcing (pemborongan kerja). Rina Herawati menyatakan bahwa terdapat setidaknya dua alasan mengapa suatu perusahaan melakukan outsourcing yaitu rendahnya biaya buruh (labour cost) dan dapat mencegah tuntutan dan pemogokan buruh. Rendahnya biaya buruh dikarenakan oleh perjanjian penyediaan jasa tenaga kerja/buruh itu sangat mirip dengan perjanjian sewa-menyewa.
Intinya adalah adanya barang yang disewakan (buruh), jangka waktu sewa (kontrak antara pemberi pekerjaan dengan penyedia jasa), dan adanya harga sewa yang umumnya sifatnya borongan atau "tau beres". Adapun maksud dari dapat mencegah tuntutan dan pemogokan yaitu buruh tidak dapat menuntut pemberi pekerjaan karena buruh tidak mempunyai hubungan kerja melainkan hubungan kerja itu ada antara buruh dengan penyedia jasa tenaga kerja. ${ }^{2}$

Outsourcing terdengar merupakan hal yang baru di dunia usaha pada saat ini. Padahal perjanjian seperti ini telah ada sejak zaman penjajahan dahulu. Hal ini diawali dengan zaman poenale sanctie. Pada tahun 1819 di Hindia Belanda telah dikenal apa yang disebut dengan hubungan perburuhan, yaitu hubungan antara buruh dengan majikan secara biasa tanpa paksaan siapa pun. Pengaturan mengenai perburuhan ini dapat dilihat dari Stb. 1819 No. 10 yang isinya antara lain menentukan bahwa perjanjian kerja dibuat secara tertulis, berlaku untuk 5 (lima) tahun, pengawasan terhadap pelaksanaan perjanjian kerja harus dilakukan oleh residen dan para pengawas pajak, dan lain sebagainya.

Namun karena perusahaan-perusahaan yang ada pada saat itu sulit untuk mendapatkan pekerja dikarenakan adanya rodi, maka pemerintah Hindia Belanda mencabut peraturan tersebut dengan Stb. 1838. Dengan adanya peraturan ini pengusaha diberikan wewenang untuk mengadakan kerja sama dengan penguasa (kepala desa). Kepala desa diberikan hak untuk mengerahkan penduduknya untuk dapat bekerja di perusahaan-perusahaan perkebunan dengan syarat pekerjaan untuk jangka waktu minimal 5 (lima) tahun, adanya upah, dan adanya perumahan dan pangan serta pekerjaan yang ditangani.

Lorna $^{3}$ dalam tulisannya "A Quick History Lesson of Outsourcing" mengatakan bahwa outsourcing telah ada sejak awal mula manusia ada di dunia. Sejak manusia sebagai mahkluk individu 
berkembang menjadi kehidupan berkelompok dan membentuk suatu masyarakat sehingga timbullah apa yang disebut dengan outsourcing. Hal ini dilakukan untuk mengatasi kekurangan masingmasing individu agar kebutuhan hidupnya dapat terpenuhi. Menurutnya perkembangan outsourcing dibagi menjadi 3 (tiga) gelombang: Pertama, outsourcing dimulai pada revolusi industri, di mana banyak jasa pelayanan didelegasikan kepada perusahaan luar dari daerah tetangga; Kedua, outsourcing dimulai dengan pendelegasian kepada pabrik dengan teknologi rendah; dan Ketiga, outsourcing dimulai dengan pendelegasian kepada pabrik dengan teknologi tinggi.

Istilah outsourcing pertama kali muncul sejak adanya uji materi terhadap Undang-Undang No. 13 Tahun 2003 tentang Ketenagakerjaan. Kemudian perkara tersebut diputus dalam Putusan Perkara No. 012/PUU-I/2003. Pasal-pasal yang diuji dalam perkara ini antara lain Pasal 64-66 yang bertentangan dengan Pasal 33 ayat (1) Undang-Undang Dasar Negara Republik Indonesia Tahun 1945 pasca perubahan. Pemohon mendalihkan bahwa UndangUndang Ketenagakerjaan menempatkan buruh/ pekerja sebagai faktor produksi semata, dengan begitu mudah dipekerjakan bila dibutuhkan untuk kemudian di-PHK ketika tidak dibutuhkan lagi. Dengan demikian komponen upah sebagai salah satu dari biaya-biaya (costs) bisa tetap ditekan seminimal mungkin. Inilah yang akan terjadi dengan dilegalkannya sistem kerja "pemborongan pekerjaan" (outsourcing) sebagaimana diatur dalam Pasal 64-66, yang akan menjadikan buruh/pekerja semata sebagai sapi perahan para pemilik modal. Sejak itulah dikenal istilah outsourcing dalam dunia ketenagakerjaan di Indonesia.

Outsourcing ada yang mengatakan bahwa sebagai modern slavery atau perbudakan modern, buruh dianggap barang dagangan yang dapat diperjualbelikan. Hal ini dinyatakan oleh ahli hukum Aloysius Uwiyono, beliau mengatakan bahwa pada dasarnya ada dua bentuk outsourcing yang hendak diperkenalkan oleh Undang-Undang Ketenagakerjaan yaitu, bentuk pertama outsourcing pekerja (Pasal 66) dan bentuk kedua outsourcing pekerjaan (Pasal 65). Menurut Aloysius Uwiyono bentuk yang pertama dapat dipandang sebagai human trafficking (perdagangan manusia). Hal ini didasarkan pada asumsi dengan adanya perjanjian, dimana perusahaan penyedia jasa menyediakan tenaga kerja dan perusahaan pengguna (user) menyerahkan sejumlah uang, maka seolah-olah terjadi penjualan tenaga kerja. Sedangkan untuk bentuk yang kedua, Uwiyono menyatakan tidak terjadi human trafficking (perdagangan manusia). Menurutnya dalam bentuk kedua ini, pekerja/ buruh masih mempunyai hubungan kerja dengan perusahaan pemborong sehingga yang terjadi di antara perusahaan penyedia jasa dengan perusahaan pemborong hanya terkait pada pemborongan kerja. ${ }^{4}$

Berdasarkan bentuk pertama yang dinyatakan oleh Uwiyono, ketentuan di dalam Pasal 66 UndangUndang Ketenagakerjaan menentukan jenis pekerjaan yang dapat dilakukan outsource yaitu kegiatan jasa penunjang atau kegiatan yang tidak berhubungan langsung dengan proses produksi.

Mahkamah Konstitusi Republik Indonesia (MKRI) pada tahun 2012 menerbitkan putusan terkait ketentuan outsourcing dengan Putusan No. 27/PUU-XI/2011. Kemudian di akhir tahun 2012 terbitlah Peraturan Menteri Tenaga Kerja dan Transmigrasi No. 19 Tahun 2012 tentang SyaratSyarat Penyerahan Sebagian Pelaksanaan Pekerjaan Kepada Perusahaan Lain. Peraturan ini terbit selain dilatarbelakangi oleh maraknya demo dan mogok nasional yang dilakukan oleh pekerja/buruh yang menuntut penghapusan outsourcing dan juga merupakan tindak lanjut dari Putusan Mahkamah Konstitusi No. 27/PUU-XI/2011.

Susunan dari peraturan menteri ini hanya terdiri dari enam bab dan 36 pasal terbilang sangat ringkas. Secara substansi, peraturan menteri ini mengatur dua keputusan menteri yang telah ada yaitu Keputusan Menteri Tenaga Kerja dan 
Transmigrasi 101/MEN/VI/2004 tentang Tata Cara Perizinan Penyediaan Jasa Pekerja/Buruh dan Keputusan Menteri Tenaga Kerja dan Transmigrasi No. Kep. 220/MEN/X/2004 tentang Syarat-Syarat Penyerahan Sebagian Pelaksanaan Pekerjaan Kepada Perusahaan Lain. Atau dengan kata lain kedua keputusan tersebut tidak berlaku.

Terlepas dari hal itu semua, salah satu hal yang akan disoroti dalam penulisan ini adalah adanya pembatasan terhadap kegiatan jasa penunjang yang dapat dilakukan outsource. Berdasarkan Pasal 17 ayat (3) Peraturan Menteri Tenaga Kerja No. 19 Tahun 2012, kegiatan jasa penunjang sebagaimana dimaksud pada ayat (2) meliputi:(1) usaha pelayanan kebersihan (cleaning service); (2) usaha penyediaan makanan bagi pekerja/buruh (catering); (3) usaha tenaga pengaman (security/satuan pengamanan); (4) usaha jasa penunjang di pertambangan dan perminyakan; dan (5) usaha penyediaan angkutan bagi pekerja/buruh. Padahal dalam penjelasan Pasal 66 Undang-Undang Ketenagakerjaan menyatakan bahwa yang dimaksud kegiatan jasa penunjang atau kegiatan yang tidak berhubungan langsung dengan proses produksi adalah kegiatan yang berhubungan di luar usaha pokok (core business) suatu perusahaan. Kegiatan tersebut antara lain usaha pelayanan kebersihan (cleaning service), usaha penyediaan makanan bagi pekerja/buruh (catering), usaha tenaga pengaman (security/ satuan pengamanan), dan usaha jasa penunjang di pertambangan, serta usaha penyediaan angkutan pekerja/buruh. Yang menjadi perhatian adalah bahwa jenis kegiatan atau kegiatan penunjang tersebut di dalam Undang-Undang Ketenagakerjaan tidak dibatasi hal ini dapat kita cermati dari katakata antara lain. Sehingga menurut penulis, peraturan menteri tersebut bertentangan dengan maksud dari Undang-Undang Ketenagakerjaan. Hal ini menjadi permasalahan jika di dalam sebuah perusahaan terdapat pekerja outsourcing yang melakukan kegiatan penunjang yang tidak disebutkan di dalam peraturan tersebut. Penulis pernah diminta untuk memberikan pendapatnya oleh salah satu perusahaan yang merasa dirugikan oleh peraturan ini. Perusahaan tersebut memiliki sub usaha outsourcing. Kegiatan outsourcing kebanyakan adalah INGO (International Non Government Organization) yang melaksanakan proyek-proyek dana hibah dari negara-negara di luar Indonesia dalam jangka waktu tertentu. Sebagai simulasi permasalahan rekanan perusahaan tersebut (sebut saja organisasi A) memiliki proyek memonitor pembangunan jalan yg didanai dengan dana hibah dari Australia. Untuk keperluan memonitor seperti ini organisasi A memerlukan 10 orang tenaga surveyor, lalu mereka minta perusahaan menyediakan sekaligus mengontrak ke 10 tenaga surveyor ini. Sehingga, kontraknya atas nama Perusahaan yang bersangkutan dan surveyor namun untuk bekerja di organisasi A ataupun di lapangan namun dengan pengawasan organisasi A. Berdasarkan simulasi permasalahan tersebut, surveyor tidak termasuk di dalam kegiatan jasa penunjang yang diatur di dalam Permenaker No. 19 Tahun 2012 tersebut tetapi menurut penulis kegiatan surveyor dapat dilaksanakan dengan perjanjian outsourcing karena sifat pekerjaannya yang dapat selesai dalam waktu tertentu dan penunjang dari kegiatan inti. Bertolak belakang pada latar belakang masalah, maka permasalahan yang diangkat dalam penulisan ini adalah bagaimanakah pengaturan outsourcing menurut Peraturan Menteri Tenaga Kerja dan Transmigrasi No. 19 Tahun 2012?

\section{B. Metode Penulisan}

Penulisan hukum merupakan suatu kegiatan ilmiah, yang didasarkan pada metode, sistematika dan pemikiran tertentu, yang bertujuan untuk mempelajari satu atau beberapa gejala hukum tertentu, dengan jalan menganalisanya. Kecuali itu, maka juga diadakan pemeriksaan yang mendalam terhadap fakta hukum tersebut, untuk kemudian mengusahakan suatu pemecahan atas permasalahanpermasalahan yang timbul di dalam gejala yang bersangkutan. ${ }^{5}$ 
Penulisan ini merupakan penulisan hukum yang bersifat normatif. Penulisan hukum normatif dilakukan dengan cara meneliti bahan pustaka atau data sekunder yang mencakup bahan hukum primer, sekunder, dan tersier. ${ }^{6}$ Menurut Amirudin S. dan Zainal Asikin ${ }^{7}$ dalam bukunya Pengantar Metode Penulisan Hukum, penulisan hukum normatif hanya mengenal data sekunder saja, yang terdiri dari bahan hukum primer, bahan hukum sekunder, dan bahan hukum tersier, maka dalam mengolah dan menganalisis bahan hukum tersebut tidak bisa lepas dari berbagai penafsiran atau pendekatan yang dikenal dalam ilmu hukum.

Penulisan ini dilakukan dengan cara studi pustaka untuk memperoleh data sekunder di bidang hukum. Penulisan kepustakaan ialah melakukan penulisan terhadap data sekunder atau disebut juga studi dokumen. ${ }^{8}$ Studi dokumen yang dilakukan adalah mengkaji dan menganalisis bahan hukum yang meliputi bahan hukum primer, sekunder, dan tersier. Bahan yang diperoleh dari hasil penulisan berupa sekunder akan dihimpun secara sistematis dan diklasifikasikan sesuai dengan permasalahan, kemudian dianalisis secara kualitatif yaitu sesuai dengan kualitas kebenarannya. Hasil penulisan dituangkan dalam bentuk deskripsi yang diharapkan dapat menjawab permasalahan rumusan pertama secara komprehensif. Hasil lain yang diharapkan berupa solusi yang tepat dan dapat diaplikasikan untuk menjawab permasalahan.

\section{Hasil Penulisan dan Pembahasan}

1. Outsourcing di Beberapa Negara di Dunia (India, Cina, dan Jerman)

Di India, Pemerintah India telah mewaspadai arti penting dan akibat outsourcing pada industri di bidang ekonomi dan sebagai hasilnya pemerintah mengumumkan bahwa industri informasi teknologi merupakan salah satu bidang yang menjadi prioritas outsourcing. Pemerintah juga telah melakukan upaya secara luas untuk mendukung sektor outsourcing dengan tujuan untuk menjamin perkembangan outsourcing. ${ }^{9}$ Untuk mendukung hal tersebut pemerintah India cenderung mengatur ketenagakerjaan lebih umum tetapi secara komprehensif. Hal ini bertujuan untuk lebih melindungi pekerja/buruh.

Di Cina, berbagai skala industri outsourcing terdapat di negeri tirai bambu ini. Sejak tahun 2007, Negara Cina sangat memfokuskan pada perlindungan pekerja/buruh. Tetapi hal ini justru menjadi penghalang bagi pengusaha dalam pelaksanaan outsourcing. Beberapa upaya yang dilakukan oleh pemerintah Cina untuk melindungi pekerjanya adalah dengan membuat suatu mekanisme perjanjian yang bersifat terbuka dan tertutup. StephanWitteler ${ }^{10}$ mengatakan pada masa lalu, pertumbuhan pasar outsourcing di Jerman terlihat lambat pertumbuhannya dan terkecil dibandingkan dengan Inggris. Pasar outsourcing yang pertama tumbuh di sektor infrastruktur secara umum dan sektor manajemen fasilitas dibandingkan dengan sektor teknologi informasi.

Salah satu hak yang dimiliki oleh direksi perusahaan di Jerman adalah hak untuk memberikan instruksi. Pada hak ini melekat kebijakan untuk mengalihkan pekerja/buruh (Transfer of Undertaking (Protection of Employment) Regulation (TUPE)), dengan tujuan untuk melindungi pekerjaan pekerja/buruh. Pengalihan ini biasanya dilakukan oleh perusahaan yang sedang melakukan akuisisi atau penggabungan perusahaan. Tetapi pengalihan ini juga dapat dilakukan dalam proses outsourcing dengan syarat, pengalihan tersebut juga meliputi pengalihan entitas ekonomi. Entitas ekonomi didefinisikan sebagai suatu kelompok sumber daya yang memiliki tujuan untuk melakukan suatu kegiatan ekonomi baik itu pekerjaan inti maupun tambahan. ${ }^{11}$

\footnotetext{
Soerjono Soekanto dan Sri Mamudji, 2006, Penulisan Hukum Normatif, Raja Grafindo Persada, Jakarta, hlm. 14. Amiruddin dan Zainal Asikin, 2004, Pengantar Metode Penulisan Hukum, Raja Grafindo Persada, Jakarta, hlm. 163. Soerjono Soekanto dan Sri Mamudji, Op.cit., hlm. 50. 
2. Pengaturan Outsourcing di Indonesia

a. Pengaturan Sebelum Undang-Undang No. 13 Tahun 2003 tentang Ketenagakerjaan

Peraturan dan pelaksanaan perjanjian outsourcing bukanlah hal yang baru di Indonesia. Sejarah perkembangan Bangsa Indonesia mencatat, pelaksanaan outsourcing telah ada sejak zaman Hindia Belanda, hal ini dapat dilihat dari Peraturan Gubernur Jenderal Hindia Belanda No. 138 tentang Koeli Ordonantie di Deli Serdang. Peraturan ini mengatur mengenai tenaga kerja yang dipekerjakan pada sektor perkebunan di wilayah lain. Kemudian peraturan tersebut diganti dengan dikeluarkannya Surat Keputusan Gubernur Hindia Belanda No. $78 . .^{12}$

Praktek outsourcing berdasarkan penjelasan Direktur Utama PT Sapta Sinergi Sourcindo, Wita Kwintika, mengemukakan penggunaan tenaga kerja outsourcing sebetulnya sudah mulai dikenal di Indonesia pada tahun 1990-an. Pola tersebut lahir karena adanya tuntutan dari persaingan bisnis yang semakin ketat. Dijelaskan dengan tingginya tingkat persaingan, pelaku bisnis harus pandai-pandai mengatur strategi melawan kompetitornya. Hal tersebut menuntut berbagai pengambilan keputusan, dilakukan dengan cepat. Agar keputusan-keputusan tetap efektif, efisien, dan produktif, lalu diupayakan untuk memperkecil rentang kendali manajemen dari para pembuat keputusan. Pada intinya, agar bisa lebih fokus di bisnis inti (core bisnis), lalu muncullah ide untuk menyerahkan pekerjaan-pekerjaan yang non-inti kepada pihak ketiga. Untuk kebutuhan ini kemudian muncullah Perusahaan Penyedia Jasa Pekerja dan mekanisme outsourcing. ${ }^{13}$

\section{b. Pengaturan Menurut Undang-Undang No. 13 Tahun 2003 dan Peraturan Pelaksananya}

Cikal bakal pengaturan outsourcing terdapat di dalam Pasal 64-66 Undang-Undang No. 13
Tahun 2003 tentang Ketenagakerjaan. Pasal 64 tentang bentuk hubungan kerja, Pasal 65 tentang syarat-syarat pelaksanaan kerja yang melindungi pekerja/buruh, dan Pasal 66 tentang jenis dan sifat pekerjaan yang dapat dilakukan dengan perjanjian pemborongan kerja atau penyediaan jasa pekerja/ buruh serta Keputusan Menteri No. KEP.101/MEN/ VI/2004 tentang Tata Cara Perizinan Perusahaan Penyedia Jasa Pekerja atau Buruh dan Keputusan Menteri No. 220/MEN/X/2004 tentang SyaratSyarat Penyerahan Sebagian Pelaksanaan Pekerjaan Kepada Perusahaan Lain.

\section{c. Pengaturan Menurut Undang-Undang No. 13 Tahun 2003 Pasca Judicial Review}

Undang-Undang No. 13 Tahun 2003 tentang Ketenagakerjaan khususnya dalam Pasal 64-66 tidak secara eksplisit menggunakan kata outsourcing tetapi praktek outsourcing yang dimaksud di dalam Undang-Undang ini ada dua yaitu, pemborongan pekerjaan dan penyediaan pekerja/buruh. Legitimasi pelaksanaan outsourcing dimulai pada saat dilakukannya judicial review pertama kali terhadap Undang-Undang No. 13 Tahun 2003 tentang Ketenagakerjaan. Di dalam Putusan Mahkamah Konstitusi No. 012/PUU-I/2003 dimuat dalam Berita Negara Republik Indonesia No. 92 Tahun 2004, terbit tanggal 17 November 2004 dalam perkara permohonan Pengujian Undang-Undang No. 13 Tahun 2003 tentang Ketenagakerjaan terhadap Undang-Undang Dasar Negara Republik Indonesia Tahun 1945. Dalam dasar argumen hukum, pihak Pemohon menyatakan: ${ }^{14}$

Undang-Undang Ketenagakerjaan menempatkan buruh/pekerja sebagai faktor produksi semata, dengan begitu mudah dipekerjakan bila dibutuhkan untuk kemudian di-PHK ketika tidak dibutuhkan lagi. Dengan demikian komponen upah sebagai salah satu dari biaya-biaya (costs) bisa tetap ditekan seminimal mungkin. Inilah yang akan

12 Dian Agung Wicaksono, "Mencari Keadilan Konstitusional Pengaturan Outsourcing di Indonesia: Diskursus Norma dan Implementasi Norma”, dalam Budi Santoso, et al., 2013, Prosiding Konferensi Nasional Ketenagakerjaan dan Hubungan Industrial, Pusat Pengembangan Hukum Ketenagakerjaan UB, Malang, hlm. 13.

13 Redaksi Pikiran Rakyat, "Outsourcing Belum Optimal”, http://www.Pikiran-Rakyat.com, diakses 7 Oktober 2006.

14 Putusan Mahkamah Konstitusi Nomor Perkara 012/PUU-I/2003 dalam perkara permohonan Pengujian Undang-Undang Nomor 13 Tahun 2003 tentang Ketenagakerjaan terhadap Undang-Undang Dasar Negara Republik Indonesia Tahun 1945. 
terjadi dengan dilegalkannya sistem kerja "pemborongan pekerjaan" (outsourcing) sebagaimana diatur dalam Pasal 64-66, yang akan menjadikan buruh/pekerja semata sebagai sapi perahan para pemilik modal.

Sejak saat itu muncullah kata outsourcing dan selalu menjadi bahan judicial review oleh para pihak yang berkepentingan. Berdasarkan pendapat Aloysius Uwiyono yang menjadi ahli yang didengarkan pendapatnya pada saat itu, beliau mengatakan bahwa ketentuan mengenai outsourcing tidak pernah diubah sejak disusunnya Undang-Undang No. 25 Tahun 1997 yang mana Undang-Undang ini tidak pernah berlaku. ${ }^{15}$

Dalam putusan itu Uwiyono menyebutkan konstruksi hubungan kerja dalam pelaksanaan outsourcing. Menurutnya konstruksi outsourcing, sebetulnya hubungan kerja yang terjadi adalah antara pengguna (user) dengan pekerja, karena perusahaan penyedia jasa pekerja, pada saat menyerahkan pekerja untuk bekerja pada pengguna, maka terjadilah hubungan hukum yang disebut hubungan kerja, karena telah ada unsur perintah, pekerjaan dan upah. ${ }^{16}$ Berdasarkan uraian tersebut, hubungan kerja tersebut timbul antara pengguna dengan pekerja sedangkan perusahaan penyedia jasa hanya sebagai perantara. Menurut penulis, hubungan yang sedemikian rupa adalah hubungan yang terjadi antara pekerja dengan perusahaan pengerah jasa TKI dan bukanlah suatu bentuk hubungan kerja dalam outsourcing. Hal ini juga senada dengan pertimbangan hukum Mahkamah Konstitusi dalam perkara tersebut yang menyatakan:

Menimbang bahwa pengaturan outsourcing dalam Pasal 64-66 Undang-Undang Ketenagakerjaan menjelaskan keberadaan dan batasan dari outsourcing tersebut sebagai bagian dari pekerjaan yang terpisah dari kegiatan utama yang merupakan kegiatan penunjang perusahaan secara keseluruhan yang tidak menghambat proses produksi secara langsung. Pelaksanaan pekerjaan tersebut diserahkan oleh suatu perusahaan kepada perusahaan lainnya dengan perjanjian pemborongan pekerjaan atau penyediaan jasa pekerja/buruh yang dibuat secara tertulis. Buruh/pekerja dimaksud tidak boleh digunakan oleh pemberi kerja untuk melaksanakan kegiatan pokok atau kegiatan yang berhubungan langsung dengan proses produksi, sehingga hubungan kerja antara buruh/pekerja outsourcing adalah dengan perusahaan penyedia jasa pekerja/buruh. ${ }^{17}$

Pertimbangan hukum lain yang disampaikan Mahkamah Konstitusi dalam putusan tersebut menyatakan bahwa:

Menimbang bahwa berdasarkan ketentuan Pasal 66 ayat (1), (2) huruf a dan c dan ayat (4), maka dalam hal buruh dimaksud ternyata dipekerjakan untuk melaksanakan kegiatan pokok, tidak ada hubungan kerja dengan perusahaan penyedia jasa pekerja/buruh, dan jika perusahaan penyedia jasa pekerja/buruh bukan merupakan bentuk usaha yang berbadan hukum, maka demi hukum status hubungan kerja antara pekerja/buruh dan perusahaan penyedia jasa pekerja/buruh beralih menjadi hubungan kerja antara pekerja/buruh dengan perusahaan pemberi pekerjaan. Oleh karena itu, dengan memperhatikan keseimbangan yang perlu dalam perlindungan terhadap pengusaha, buruh/pekerja dan masyarakat secara selaras, dalil para Pemohon tidak cukup beralasan. Hubungan kerja antara buruh dengan perusahaan penyedia jasa yang melaksanakan pelaksanaan pekerjaan pada perusahaan lain, sebagaimana diatur dalam Pasal 64-66 Undang-Undang a quo, mendapat perlindungan kerja dan syarat-syarat yang sama dengan perlindungan kerja dan syarat-syarat kerja pada perusahaan pemberi pekerjaan atau sesuai dengan peraturan perundang-undangan yang berlaku. Oleh karenanya, terlepas dari jangka waktu tertentu yang mungkin menjadi syarat perjanjian kerja demikian dalam kesempatan yang tersedia, maka perlindungan hak-hak buruh sesuai dengan aturan hukum dalam Undang-Undang

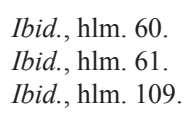


Ketenagakerjaan, tidak terbukti bahwa hal itu menyebabkan sistem outsourcing merupakan modern slavery dalam proses produksi. ${ }^{18}$

Pertimbangan Mahkamah Konstitusi tersebut sekaligus mematahkan pendapat Uwiyono. Beliau menyampaikan bahwa di dalam sistem outsourcing, konstruksi hukumnya yaitu adanya suatu perusahaan penyedia jasa pekerja merekrut calon pekerja untuk ditempatkan di perusahaan pengguna. Jadi di sini diawali suatu hubungan hukum atau suatu perjanjian antara perusahaan penyedia jasa pekerja dengan perusahaan pengguna pekerja. Perusahaan penyedia jasa pekerja mengikatkan dirinya untuk menempatkan pekerja di perusahaan pengguna, dan perusahaan pengguna mengikatkan dirinya untuk menggunakan pekerja tersebut. Berdasarkan perjanjian penempatan tenaga kerja, perusahaan penyedia jasa pekerja akan mendapatkan sejumlah uang dari pengguna. Untuk 100 orang misalnya Rp 10.000.000,00, kemudian perusahaan penyedia jasa pekerja akan mengambil sekian persen, sisanya dibayarkan kepada pekerja yang bekerja di perusahaan pengguna. Jadi konstruksi hukum semacam ini merupakan perbudakan, karena pekerja-pekerja tersebut dijual kepada pengguna dengan jumlah uang. Hal ini merupakan perbudakan modern. ${ }^{19}$

Pertanyaan yang dapat timbul dari pendapat tersebut yaitu bagaimana jika pola atau sudut pandang terhadap perusahaan penyedia jasa tersebut diubah. Perusahaan pengguna mengadakan perjanjian dengan Perusahaan penyedia jasa untuk melakukan suatu pekerjaan dengan kontrak dan jangka waktu tertentu. Perusahaan penyedia jasa menempatkan pekerjanya di perusahaan pengguna untuk melakukan pekerjaan tertentu dengan upah dan perintah dari pihak penyedia jasa dalam waktu tertentu berdasarkan kesepakatan yang telah dibuat antara perusahaan pengguna dengan penyedia jasa. Apakah hal ini juga dapat dikatakan perbudakan? Menurut penulis hal ini tidak dapat dikatakan perbudakan, karena pekerja diberikan upah dan perlindungan sebagaimana terdapat di dalam Undang-Undang Ketenagakerjaan. Hal ini sesuai dengan Pasal 66 ayat (2) huruf d Undang-Undang Ketenagakerjaan yang berbunyi: "Perjanjian antara perusahaan pengguna jasa pekerja/buruh dan perusahaan lain yang bertindak sebagai perusahaan penyedia jasa pekerja/buruh dibuat secara tertulis dan wajib memuat pasal-pasal sebagaimana dimaksud dalam Undang-Undang ini”. Dengan demikian, perjanjian yang dibuat oleh para pihak harus sesuai dengan ketentuan-ketentuan perlindungan hukum pekerja/buruh yang terdapat di dalam Undang-Undang Ketenagakerjaan.

Penulis berpendapat bahwa pemikiran yang sedemikian rupa dapatlah direkayasa, tinggal dari sudut pandang mana kita melihatnya. Hal yang sama juga disampaikan di dalam pertimbangan hukumnya yang menyatakan:

Menimbang bahwa anggapan para Pemohon bahwa Undang-Undang Ketenagakerjaan memandang buruh hanya sebagai komoditi, karena kecenderungan sistem outsourcing dalam pola pekerjaan yang juga dianggap sebagai modern slavery, Mahkamah berpendapat bahwa para Pemohon tidak dapat membuktikan dasar dari dalil tersebut, karena dalam keseluruhan ketentuan Undang-Undang a quo tidak memuat aturan yang menunjuk pada hal yang didalilkan, meskipun benar bahwa pola outsourcing telah diatur secara khusus dalam Pasal 64-66 Undang-Undang $a$ quo. ${ }^{20}$

Amar Putusan Mahkamah Konstitusi No. Perkara 012/PUU-I/2003 menyatakan bahwa menolak gugatan pemohon terkait Pasal 64-66 Undang-undang Ketenagakerjaan atau dengan kata lain Pasal 64-66 Undang-undang Ketenagakerjaan tidak bertentang dengan Pasal 33 Undang-Undang Dasar Negara Republik Indonesia Tahun 1945. Perjuangan pencari keadilan terhadap Undangundang Ketenagakerjaan tidak sampai disana. Hal ini terbukti dari permohonan judicial review 
terhadap Undang-Undang Ketenagakerjaan. Tercatat terdapat 7 (tujuh) permohonan yang telah diajukan oleh berbagai pihak ke Mahkamah Konstitusi.

Perhatian penulis tertuju pada Putusan Mahkamah Konstitusi No. Perkara 27/PUUIX/2011. Permohonan ini diajukan oleh Didik Suprijadi, dalam hal ini bertindak atas nama Lembaga Swadaya Masyarakat Aliansi Petugas Pembaca Meter Listrik Indonesia (AP2ML). Pada permohonannya disebutkan bahwa Undang-Undang yang dimohonkan untuk diuji terhadap UndangUndang Dasar Negara Republik Indonesia Tahun 1945 adalah Undang-Undang No. 13 Tahun 2003 tentang Ketenagakerjaan, Pasal 59 yang mengatur tentang Perjanjian Kerja Waktu Tertentu (pekerja kontrak) dan Pasal 64 yang mengatur tentang penyerahan sebagian pelaksanaan pekerjaan kepada perusahaan lainnya (outsourcing) yang memiliki dampak langsung dan tidak langsung kepada semua buruh/pekerja kontrak dan buruh/pekerja outsourcing yang ada di Indonesia dan sangat merugikan hak-hak konstitusionalnya yang diatur dalam Undang-Undang Dasar Negara Republik Indonesia Tahun 1945, yaitu mengenai hak atas pekerjaan dan penghidupan yang layak bagi kemanusiaan, hak untuk bekerja serta mendapat imbalan dan perlakuan yang adil dan layak dalam hubungan kerja dan hak atas kesejahteraan dan kemakmuran. $^{21}$

Dalam permohonannya, Didik ${ }^{22}$ juga menyampaikan bahwa setiap warga negara berhak atas pekerjaan dan penghidupan yang layak bagi kemanusiaan sudah sejak awal berdirinya negara ini ditetapkan sebagai hak asasi manusia warga negara yang secara khusus telah dimuat di dalam Undang-Undang Dasar Negara Republik Indonesia Tahun 1945 yang menjadi dasar konstitusional negara ini dan hak untuk bekerja serta mendapat imbalan dan perlakuan yang adil dan layak dalam hubungan kerja juga ditetapkan sebagai hak asasi manusia warga negara yang secara khusus telah dimuat di dalam Undang-Undang Dasar Negara Republik Indonesia Tahun 1945 yang menjadi dasar konstitusional negara ini.

Tuntutan dari permohonan ini lebih menekankan peran negara sebagai pelindung segenap bangsa dan tumpah darah guna memajukan kesejahteraan umum yang tidak dirasakan peranannya. Perlindungan tersebut dapat tercermin dari peraturan perundang-undangan, dalam hal ini pemohon melihat bahwa Pasal 59 dan Pasal 64 Undang-undang Ketenagakerjaan bertentangan dengan Pasal 27 ayat (2), Pasal 28D, dan Pasal 33 ayat (1) Undang-Undang Dasar Negara Republik Indonesia Tahun 1945. Kedua pasal yang diajukan tersebut menurut pemohon hanya menempatkan pekerja/buruh sebagai faktor produksi semata, dengan begitu mudah dipekerjakan bila dibutuhkan dan diputus hubungan kerjanya ketika tidak dibutuhkan lagi karena didasarkan pada sistem perjanjian kerja waktu tertentu menurut jenis pekerjaannya. Dengan demikian, komponen upah sebagai salah satu dari biaya-biaya (cost) bisa tetap ditekan seminimal mungkin.

Pasal 33 ayat (1) Undang-Undang Dasar Negara Republik Indonesia Tahun 1945 yang menyatakan "Perekonomian disusun sebagai usaha bersama berdasar atas asas kekeluargaan". Di dalam penjelasannya ditegaskan lagi bahwa ini artinya perekonomian kita berdasarkan pada demokrasi ekonomi, dimana produksi dikerjakan oleh semua, untuk semua dengan kemakmuran masyarakatlah yang diutamakan. Dengan dilegalkannya outsourcing yang terkandung di dalam kedua pasal tersebut, pemohon menyatakan "di sinilah akan timbul apa yang disebut dengan perbudakan modern".

Pertimbangan majelis hakim ${ }^{23}$ menyebutkan menimbang bahwa Pemohon mendalilkan, norma

\footnotetext{
21 Putusan Mahkamah Konstitusi Nomor PUU 027/PUU-IX/2011 dalam perkara permohonan Pengujian Undang-Undang No. 13 Tahun 2003 tentang Ketenagakerjaan terhadap Undang-Undang Dasar Negara Republik Indonesia Tahun 1945.

2 Ibid., hlm. 4

23 Ibid., hlm. 37.
} 
yang mengatur Perjanjian Kerja Waktu Tertentu (PKWT) dalam Pasal 59 Undang-Undang No. 13 Tahun 2003 tidak memberikan jaminan kelanjutan kerja bagi pekerja/buruh, serta tidak memberikan jaminan atas hak-hak pekerja/buruh yang lainnya. Menurut Mahkamah, PKWT sebagaimana diatur dalam Pasal 59 Undang-Undang No. 13 Tahun 2003 adalah jenis perjanjian kerja yang dirancang untuk pekerjaan yang dimaksudkan hanya untuk waktu tertentu saja dan tidak berlangsung untuk selamanya, sehingga hubungan kerja antara buruh dan majikan akan berakhir begitu jangka waktu berakhir atau ketika pekerjaan telah selesai dikerjakan. Oleh karena itu, Pasal 59 Undang-Undang No. 13 Tahun 2003 menegaskan bahwa PKWT hanya dapat diterapkan untuk 4 (empat) jenis pekerjaan, yaitu: (i) pekerjaan yang sekali selesai atau yang sementara sifatnya; (ii) pekerjaan yang diperkirakan dapat diselesaikan dalam waktu yang tidak terlalu lama dan paling lama 3 (tiga) tahun; (iii) pekerjaan yang bersifat musiman; (iv) pekerjaan yang berhubungan dengan produk baru, kegiatan baru, atau produk tambahan yang masih dalam percobaan atau penjajakan, dan bersifat tidak tetap.

Terhadap hal tersebut di atas, penulis berpendapat bahwa terdapat jenis pekerjaan yang sifatnya terus menerus atau pun tetap sifatnya tetapi juga terdapat jenis pekerjaannya yang sifatnya sementara atau tidak tetap. Dari pernyataan ini, berkonsekuensi pada jenis perjanjian kerja yang diatur di dalam Undang-Undang Ketenagakerjaan, untuk jenis pekerjaan yang sifatnya tetap biasanya atau dapat didasarkan pada perjanjian yang sifatnya tetap begitu pula sebaliknya. Raison de 'etre dari hal ini adalah pekerja yang bekerja di sektor pekerjaan yang sifatnya sementara haruslah paham konsekuensi hukum dari sifat pekerjaan tersebut. Pada prinsipnya, Undang-Undang Ketenagakerjaan telah memberikan perlindungan yang cukup bagi para pihak, tetapi yang terjadi adalah pelaksanaan terhadap Undang-Undang Ketenagakerjaan (Pengawasan Ketenagakerjaan) belumlah optimal hal ini disebabkan oleh terbatasnya jumlah pegawai pengawas yang ada.
Langkah penting yang diambil Majelis Hakim terhadap tidak terjaminnya pekerja atas pekerjaannya yang bersifat sementara tersebut. Mahkamah Konstitusi menetapkan dua model konstruksi hukum model yang pertama adalah perjanjian kerja antara pekerja/buruh dengan perusahaan yang melakukan outsourcing didasarkan pada Perjanjian Kerja Waktu Tidak Tertentu. Model yang kedua adalah apabila perjanjian kerja didasarkan pada perjanjian kerja waktu tertentu maka di dalam perjanjian tersebut harus mencantumkan suatu prosedur yang disebut dengan Transfer of Undertaking Protection of Employment (TUPE). TUPE merupakan prinsip pengalihan tindakan perlindungan bagi pekerja/buruh yang bekerja pada perusahaan yang melaksanakan pekerjaan outsourcing. Padahal, hal ini sudah pernah diajukan dalam permohonan sebelumnya yaitu pada Permohonan perkara permohonan pengujian Undang-Undang No. 13 Tahun 2003 tentang Ketenagakerjaan terhadap Undang-Undang Dasar Negara Republik Indonesia Tahun 1945 No. 012/PUU-I/2003 yang pada intinya Mahkamah Konstitusi menyatakan bahwa pekerja/buruh mendapat perlindungan kerja dan syarat-syarat yang sama dengan perlindungan kerja dan syarat-syarat kerja pada perusahaan pemberi pekerjaan atau sesuai dengan peraturan perundangundangan yang berlaku. Oleh karenanya, terlepas dari jangka waktu tertentu yang mungkin menjadi syarat perjanjian kerja demikian dalam kesempatan yang tersedia, maka perlindungan hak-hak buruh sesuai dengan aturan hukum dalam Undang-Undang Ketenagakerjaan.

\section{d. Pengaturan Outsourcing Menurut Per- aturan Menteri Tenaga Kerja dan Trans- migrasi No. 19 Tahun 2012 tentang Syarat- Syarat Penyerahan Sebagian Pelaksanaan Pekerjaan Kepada Perusahaan Lain}

Tindak lanjut dari Putusan Mahkamah Konstitusi No. Perkara 027/PUU-IX/2011 yaitu diberlakukanlah Peraturan Menteri Tenaga Kerja dan Transmigrasi No. 19 Tahun 2012 tentang Syarat-Syarat Penyerahan sebagian Pelaksanaan Pekerjaan Kepada Perusahaan Lain. Menurut 
penulis batang tubuh dari peraturan menteri tersebut hanya mengulang dari peraturan perundangundangan yang sudah ada, sebagai contoh Pasal 2 yang berbunyi: "Penyerahan sebagian pelaksanaan pekerjaan kepada perusahaan lain dapat dilakukan melalui perjanjian pemborongan pekerjaan atau perjanjian penyediaan jasa pekerja/buruh". Hal ini sama dengan bunyi ketentuan dalam Pasal 64 Undang-Undang Ketenagakerjaan "Perusahaan dapat menyerahkan sebagian pelaksanaan pekerjaan kepada perusahaan lainnya melalui perjanjian pemborongan pekerjaan atau penyediaan jasa pekerja/buruh yang dibuat secara tertulis".

Hal yang sama juga ditemukan di dalam Pasal 3, ketentuan Pasal 3 hanya mengulang apa yang ada di dalam Pasal 65 ayat (1) dan (2). Selain itu beberapa ketentuan lainnya juga merupakan "cabutan" dari Peraturan Menteri Ketenagakerjaan dan Transmigrasi No. KEP.101/MEN/VI/2004 tentang Tata Cara Perizinan Penyediaan Jasa Pekerja/Buruh dan Keputusan Menteri Tenaga Kerja dan Transmigrasi No. KEP.220/MEN/X/2004 tentang Syarat-Syarat Penyerahan Sebagian Pelaksanaan Pekerjaan Kepada Perusahaan Lain yang dinyatakan tidak berlaku oleh Peraturan Menteri ini. Pada prinsipnya bahwa peraturan menteri tidak boleh bertentangan dengan peraturan perundangundangan yang berlaku.

Fokus penulis pada peraturan menteri ini adalah terkait dengan penentuan jenis pekerjaan atau kegiatan penunjang yang menjadi objek perjanjian dan pelaksanaan Transfer of Undertaking Protection of Employment yang terkandung di dalam Pasal 28 dan 29 Peraturan Menteri ini. Terkait fokus yang pertama, Peraturan Menteri ini mengatur bahwa pekerjaan yang dapat diserahkan kepada perusahaan penyedia jasa pekerja/buruh adalah kegiatan jasa penunjang atau yang tidak berhubungan langsung dengan proses produksi (Pasal 17 ayat (2)). Kegiatan jasa penunjang tersebut meliputi usaha pelayanan kebersihan, penyediaan makanan bagi pekerja/bu- ruh, usaha tenaga pengaman, usaha jasa penunjang di pertambangan, dan penyediaan angkutan bagi pekerja/buruh. Berdasarkan hasil penulisan pustaka, kata meliputi di sini bermakna "mencakup"24 yang tidak berarti membatasi. Penulis menduga maksud pembuat peraturan perundang-undangan adalah memberikan batasan jenis atau kegiatan jasa penunjang. Padahal di dalam penjelasan Undang-Undang Ketenagakerjaan tidak membatasi kegiatan jasa penunjang tetapi memberikan contoh kegiatan jasa penunjang dengan menggunakan kata antara lain. ${ }^{25}$

Penulis berpendapat bahwa pembatasan sedemikian rupa bertentangan dengan asas kebebasan berkontrak dimana seseorang bebas untuk menentukan objek perjanjian. Memang kebebasan di sini tidaklah sebebas-bebasnya tetap dibatasi. Tetapi menurut Penulis pembatasan yang dilakukan disini justru tidak memberikan manfaat bagi orang lain. Selain itu, jika bercermin ke beberapa negara tetangga yang penulis telah uraikan di atas, jenis kegiatan jasa penunjang lebih pada kegiatan-kegiatan jasa baik itu di bidang teknologi informasi, infrastruktur, dan lain sebagainya.

Fokus yang kedua yaitu penerapan TUPE di dalam peraturan ini. TUPE pada awalnya dikenalkan di Inggris pada tahun 1981. Pengaruh TUPE pada saat itu memang tidak serta merta tetapi pada akhirnya bertumbuh. Pada umumnya TUPE diterapkan pada perusahaan yang melakukan akuisisi ataupun merger. Akan tetapi, pelaksanaan TUPE dapat juga untuk 2 (dua) alternatif yang lain. Alternatif pertama adalah terjadinya pengalihan entitas ekonomi dan alternatif yang kedua adalah adanya perubahan peraturan dalam pelayanan. TUPE merupakan kebijakan yang melekat pada direksi dengan hak memerintahnya. ${ }^{26}$

Berdasarkan uraian di atas dapat timbul pertanyaan, apakah TUPE dapat diterapkan pada proses outsourcing di Indonesia? Berdasarkan hasil penelusuran penulis mengenai Undang-Undang No. 40 Tahun 2007 tentang Perseroan Terbatas, Pasal

\footnotetext{
Departemen Pendidikan dan Kebudayaan, 2006, Kamus Besar Bahasa Indonesia, Balai Pustaka, Jakarta.

Periksa Penjelasan Pasal 66 ayat (1) Undang-Undang Nomor 13 Tahun 2003 tentang Ketenagakerjaan (Tambahan Lembaran Negara Republik Indonesia Nomor 4279).

26 Amanda Lewis and Denton Wilde Sapte, Op.cit., hlm. 232.
} 
123 ayat (1) berbunyi Direksi Perseroan yang akan menggabungkan diri dan menerima penggabungan menyusun rancangan penggabungan dan ayat (2) huruf $h$ berbunyi rancangan penggabungan tersebut termasuk cara penyelesaian status, hak dan kewajiban anggota direksi, dewan komisaris, dan karyawan perseroan yang akan melakukan penggabungan diri. Berdasarkan hal tersebut penulis berpendapat proses outsourcing yang pada umumnya terjadi di Indonesia belum dapat dikatakan sebagai suatu proses penggabungan perusahaan atau pengambilalihan perusahaan. Proses outsourcing di Indonesia masih bersifat terpisah antara perusahaan pengguna dengan penyedia. Selain itu, juga melihat jenis kegiatan jasa penunjang yang beroperasi di Indonesia masih pada tahapan unskilled sectors dan tujuan dari penerapan outsourcing adalah menekan biaya. Jika terjadi penggabungan atau pengambilalihan perusahaan, jelas hal ini akan mengeluarkan banyak biaya.

Bagaimanakah dengan penerapan outsourcing di Indonesia dengan alternatif yang pertama? Proses outsourcing di Indonesia sebagaimana penulis telah sampaikan masih bersifat terpisah. Perusahaan pengguna sangat menghindari berhubungan secara langsung dengan pekerja/buruh sehingga dalam berkomunikasi melalui pihak perusahaan penyedia dalam konteks hak dan kewajiban dalam perjanjian kerjasama. Sehingga tidak terdapat pengalihan entitas ekonomi dari perusahaan pengguna kepada perusahaan penyedia jasa. Sedangkan untuk alternatif kedua, penulis belum menemukan peraturan yang spesifik mengatur mengenai pelayanan. Selain itu juga, Pasal 65 ayat (4) dan Pasal 66 ayat (4) Undang-Undang Ketenagakerjaan telah memberikan perlindungan kepada pekerja/ buruh. Pasal 65 ayat (4) berbunyi: "Perlindungan kerja dan syarat-syarat kerja bagi pekerja/buruh pada perusahaan lain sebagaimana dimaksud pada ayat (2) sekurang-kurangnya sama dengan perlindungan kerja dan syarat-syarat kerja pada perusahaan pemberi pekerjaan atau sesuai dengan peraturan perundang-undangan yang berlaku". Pasal 66 ayat (4) berbunyi Dalam hal ketentuan sebagaimana dimaksud pada ayat (1), ayat (2) huruf a, huruf b, dan huruf d serta ayat (3) tidak terpenuhi, maka demi hukum status hubungan kerja antara pekerja/buruh dan perusahaan penyedia jasa pekerja/buruh beralih menjadi hubungan kerja antara pekerja/buruh dan perusahaan pemberi pekerjaan. Dengan demikian, secara tidak langsung konsep TUPE sudah diadopsi dalam Undang-Undang Ketenagakerjaan.

\section{Kesimpulan}

Kesimpulan yang dapat diambil dari penulisan ini yaitu pengaturan outsourcing menurut Peraturan Menteri Ketenagakerjaan dan Transmigrasi No. 19 Tahun 2012 masih belumlah tepat. Hal ini dapat dilihat dari adanya pembatasan terkait kegiatan jasa penunjang yang hanya mencakup 5 (lima) kegiatan jasa penunjang yang notabene merupakan pekerjaan unskilled sectors. Hal yang kedua yaitu penerapan TUPE yang masih belum tepat karena belum sesuai dengan konteks dan maksud pelaksanaan TUPE yang telah diterapkan di beberapa negara di Asia dan Eropa dan pada kenyataan konsep ini telah diadopsi di Pasal 65 dan 66 UndangUndang Ketenagakerjaan. Saran yang dapat penulis sampaikan adalah dalam menindaklanjuti sebuah putusan, sudah benar pemerintah menindaklanjuti dengan cepat tetapi juga tetap mempertimbangkan aspek penting lainnya, misalnya penyesuaian konteks permasalahan dengan kerangka hukum yang berlaku dan/atau kerangka hukum yang akan diberlakukan. Hal ini menjadi penting agar tindakan yang telah diambil tidak sia-sia.

\section{DAFTAR PUSTAKA}

\section{A. Buku}

Amiruddin dan Zainal Asikin, 2004, Pengantar Metode Penulisan Hukum, Raja Grafindo Persada, Jakarta.
Lewis, Amanda dan Denton Wilde Sapte, 2009, Outsourcing Contracts-A Practice Guide, Thomson Reuters, London. 
Sinaga, Marsen, 2006, Pengadilan Perburuhan di Indonesia, Perhimpunan Solidaritas Buruh, Yogyakarta.

Soekanto, Soerjono, 1986, Pengantar Penulisan Hukum, Universitas Indonesia Press, Jakarta.

Soekanto, Soerjono dan Sri Mamudji, 2006, Penulisan Hukum Normatif, Raja Grafindo Persada, Jakarta.

Departemen Pendidikan dan Kebudayaan, 2006, Kamus Besar Bahasa Indonesia, Balai Pustaka, Jakarta.

\section{B. Artikel dalam Antologi}

Wicaksono, Dian Agung, "Mencari Keadilan Konstitusional Pengaturan Outsourcing di Indonesia: Diskursus Norma dan Implementasi Norma", dalam Budi Santoso, et al., 2013, Prosiding Konferensi Nasional Ketenagakerjaan dan Hubungan Industrial, Pusat Pengembangan Hukum Ketenagakerjaan UB, Malang.

\section{Peraturan Perundang-Undangan}

Undang-Undang Dasar Negara Republik Indonesia Tahun 1945 pasca Amandemen ke-IV.

Kitab Undang-Undang Hukum Perdata (BW).

Undang-Undang No. 3 Tahun 1951 tentang Pernyataan Berlakunya Undang-Undang Pengawasan Perburuhan Tahun 1948 No. 23 dari Republik Indonesia untuk Seluruh Indonesia.

Undang-Undang No. 13 Tahun 2003 Tentang Ketenagakerjaan (Lembaran Negara Republik Indonesia Tahun 2003 No. 39, Tambahan Lembaran Negara Republik Indonesia No. 4279).

Peraturan Menteri Tenaga Kerja dan Transmigrasi No. 19 Tahun 2012 tentang Syarat-Syarat Penyerahan Sebagian Pelaksanaan Pekerjaan kepada Perusahaan Lain.

Keputusan Menteri No. 233/MEN/2003 tentang Jenis dan Sifat Pekerjaan yang Dijalankan secara Terus-Menerus.
Keputusan Menteri No. 100/MEN/VI/2004 tentang Pelaksanaan Perjanjian Kerja Waktu Tertentu. Keputusan Menteri No. 101/MEN/VI/2004 tentang Tata Cara Perizinan Perusahaan Penyedia Jasa Pekerja atau Buruh.

Keputusan Menteri No. 220/MEN/X/2004 tentang Syarat-syarat Penyerahan Sebagian Pelaksanaan Pekerjaan kepada Perusahaan Lain.

Surat Edaran Direktur Jenderal Pembinaan Hubungan Industrial dan Jaminan Sosial Tenaga Kerja dan Transmigrasi No. B. 31/ PHIJSK/I/2012 tentang Pelaksanaan Putusan Mahkamah Konstitusi No. 27/PUU-IX/2011.

\section{Website}

Herawati, Rina, "Outsourcing, Mengapa Harus Diwaspadai", http://www.akatiga.or.id, diakses 7 Oktober 2006.

Lorna, "A Quick History Lesson of Outsourcing", http://www.lifeonline.com, diakses 29 Februari 2008.

Uwiyono, Aloysius, "Outsourcing Tenaga Kerja Dapat Dianggap Human Trafficking", http:// www.hukumonline.com, diakses 7 Oktober 2006.

, "Outsourcing Belum Optimal", http:// www.pikiranrakyat.com, diakses 7 Oktober 2006.

\section{E. Putusan Pengadilan}

Putusan Mahkamah Konstitusi No. Perkara 012/ PUU-I/2003 dalam perkara permohonan Pengujian Undang-Undang Nomor 13 Tahun 2003 tentang Ketenagakerjaan terhadap Undang-Undang Dasar Negara Republik Indonesia Tahun 1945.

Putusan Mahkamah Konstitusi No. PUU 027/ PUU-IX/2011 dalam perkara permohonan Pengujian Undang-Undang No. 13 Tahun 2003 tentang Ketenagakerjaan terhadap Undang-Undang Dasar Negara Republik Indonesia Tahun 1945. 